\title{
Cardiovascular tissue banking in Croatia
}

\author{
I Safradin ${ }^{\text {1*}, ~ B ~ G o l u b i c ~ C e p u l i c ~}{ }^{2}$, M Golemovic ${ }^{2}$, R Habekovic ${ }^{1}$, M Borojevic ${ }^{1}$, M Skific ${ }^{1}$, D Jelasic ${ }^{3}$, I Marekovic ${ }^{4}$, \\ S Ivankovic', B Biocina' \\ From 23rd World Congress of the World Society of Cardio-Thoracic Surgeons \\ Split, Croatia. 12-15 September 2013
}

\section{Background}

The Croatian Cardiovascular Tissue Bank (CTB) was established in June 2011 at University Hospital Centre Zagreb (UHC). Cardiovascular tissues processed in CTB were retrieved and processed according to validated protocols and in compliance with laws and regulations applied in tissue establishments.

\section{Methods}

Cardiovascular tissue allografts (CVA) were retrieved from recipients of heart transplants (RHT) and multiorgan donors (MOD) which fulfill donor selection criteria. Processing of CVA was performed in CTB clean room (GMP Class B). Initial processing included surgical dissection, measurements, morphology and functional assessment and collection of quality control samples. CVA were incubated in antibiotic containing medium (vancomycin, lincomycin, polymyxin B sulfate) for 24-48 hours. Then CVA were cryopreserved in solution containing $10 \%$ of dimethylsulphoxyde and stored in vapor phase of liquid nitrogen. Cryopreserved tissues remained in the quarantine until all quality control results were collected.

\section{Results}

During time period from June 2011 to March 2013, 63 cardiovascular tissue allografts were retrieved from 35 donors (17 RHT and 18 MOD). 32 CVA were accepted for clinical use. Accepted tissues were as follows 15 aortic valves, 13 pulmonary valves, 4 thoracic aortas. $10 \mathrm{CVA}$ remained in quarantine and 21 CVA were discarded. Reasons for CVA to be discarded were microbiological, serological and morphological. 12 CVA ( 9 aortic valves and 3 thoracic aortas) were successfully transplanted since

\footnotetext{
* Correspondence: safradini@gmail.com

${ }^{1}$ Department of Cardiac Surgery, University Hospital Centre Zagreb, Zagreb, Croatia

Full list of author information is available at the end of the article
}

June 2012. Indications were infectious (7 patients), noninfectious ( 2 patients) and congenital (1 patient).

\section{Conclusion}

The cardiovascular tissue bank was successfully established at UHC Zagreb. CTB needs to work on the rising of public and surgeons awareness about cardiovascular tissue donation in order to achieve large selection of high quality cardiovascular tissue allografts. Initial clinical results are encouraging.

\section{Authors' details}

${ }^{1}$ Department of Cardiac Surgery, University Hospital Centre Zagreb, Zagreb, Croatia. ${ }^{2}$ Department of Transfusion Medicine and Transplantation Biology, University Hospital Centre, Zagreb, Croatia. ${ }^{3}$ Department of Pathology and Cytology, University Hospital Centre Zagreb, Zagreb, Croatia. ${ }^{4}$ Department of Microbiology, University Hospital Centre Zagreb, Zagreb, Croatia.

Published: 11 September 2013

doi:10.1186/1749-8090-8-S1-P86

Cite this article as: Safradin et al:: Cardiovascular tissue banking in Croatia. Journal of Cardiothoracic Surgery 2013 8(Suppl 1):P86.

\section{Submit your next manuscript to BioMed Central and take full advantage of: \\ - Convenient online submission \\ - Thorough peer review \\ - No space constraints or color figure charges \\ - Immediate publication on acceptance \\ - Inclusion in PubMed, CAS, Scopus and Google Scholar \\ - Research which is freely available for redistribution

C Biomed Central

C 2013 Safradin et al; licensee BioMed Central Ltd. This is an Open Access article distributed under the terms of the Creative Commons Attribution License (http://creativecommons.org/licenses/by/2.0), which permits unrestricted use, distribution, and reproduction in any medium, provided the original work is properly cited. 